Click www.researchjournal.co.in/online/subdetail.html to purchase.

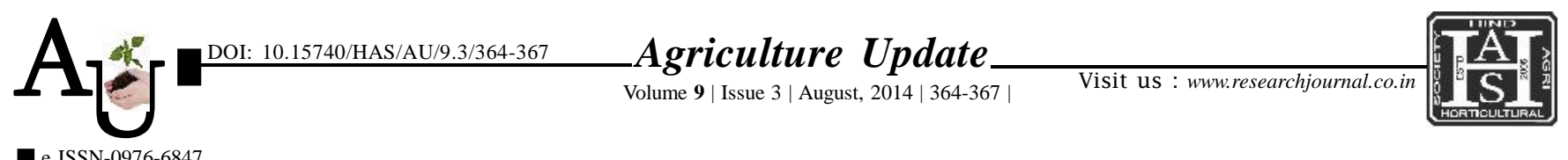

Research Article

\title{
Attitude of farmers towards organic vegetable cultivation
}

D. JAMES MOHAN AND S. HELEN

Article Chronicle: Summary : Realizing the adverse effects of conventional farming, organic farming is gaining momentum in Received :

04.04.2013;

Revised :

17.06.2014;

Accepted :

01.07.2014

KeY Words:

Attitude, Organic

farmers, Conventional

farmers, Organic

vegetable cultivation
India. The general public started searching for organic produce. Conventional farmers are aiming for higher productivity and profitability. There exists a wide gap between demand and production of organic produce. Therefore, a systematic study was conducted with the objective of analyzing the attitude of farmers towards the cultivation of organic vegetables who are now engaged in organic and conventional vegetable cultivation. Majority of the organic farmers $(86.67 \%$ ) had a favourable attitude towards organic farming practices followed by more favourable (10\%) and less favourable (3.33\%) attitude. More than 80 per cent of the conventional farmers had favourable attitude towards organic farming practices. Above 90 per cent of the organic as well as conventional farmers believed that use of organic farming practices was essential for better quality of vegetables. Nearly cent per cent of the conventional farmers reduced the chemical application over the years and increased the application

How to cite this article : Mohan D. James and Helen, S. (2014). Attitude of farmers towards organic vegetable cultivation. Agric. Update, 9(3): 364-367. of organic manures.
Author for correspondence :

\section{S. HELEN}

Communication Centre, Kerala Agricultural University, THRISSUR (KERALA) INDIA

Email: helen.s@kau.in

See end of the article for authors' affiliations 